4 nordon 



\section{"Sustainable Production of Bioenergy from Agriculture and Forestry in the Nordic Countries”}


"Sustainable Production of Bioenergy from Agriculture and Forestry in the Nordic Coun

TemaNord 2009:511

(C) Nordic Council of Ministers, Copenhagen 2009

ISBN 978-92-893-1833-4

Print:

Cover:

Layout:

Cover photo:

Copies: 0

Printed on environmentally friendly paper

This publication can be ordered on www.norden.org/order. Other Nordic publications are available at www.norden.org/publications

Printed in Denmark

Nordic Council of Ministers

Store Strandstræde 18

DK-1255 Copenhagen K

Phone (+45) 33960200

Fax (+45) 33960202
Nordic Council

Store Strandstræde 18

DK-1255 Copenhagen K

Phone (+45) 33960400

Fax (+45) 33111870

www.norden.org

\section{Nordic co-operation}

Nordic cooperation is one of the world's most extensive forms of regional collaboration, involving Denmark, Finland, Iceland, Norway, Sweden, and three autonomous areas: the Faroe Islands, Greenland, and Åland.

Nordic cooperation has firm traditions in politics, the economy, and culture. It plays an important rol in European and international collaboration, and aims at creating a strong Nordic community in a strong Europe.

Nordic cooperation seeks to safeguard Nordic and regional interests and principles in the global community. Common Nordic values help the region solidify its position as one of the world's most innovative and competitive. 


\section{Content}

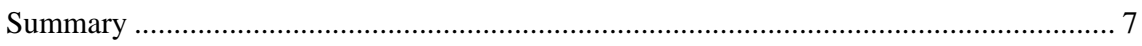

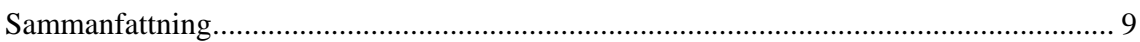

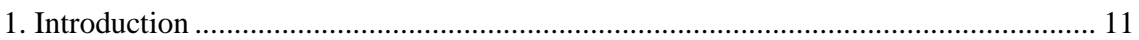

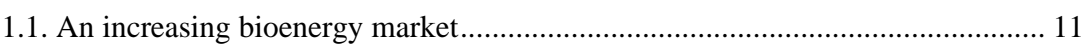

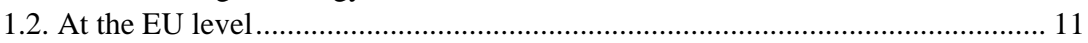

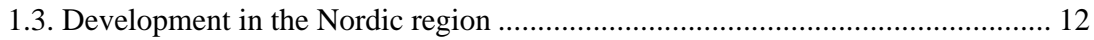

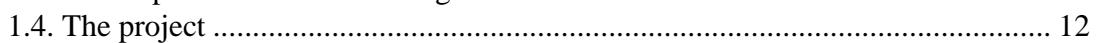

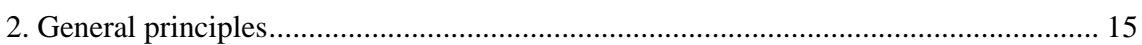

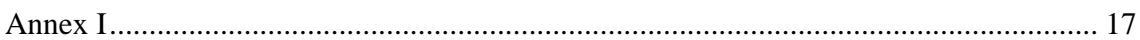

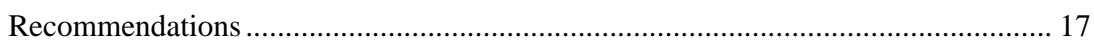

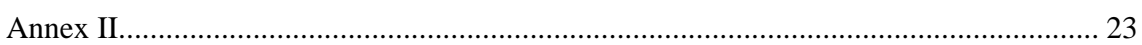





\section{Summary}

In EU member states as well as in other parts of the world, energy policies are being developed that discriminate fossil fuels and /or promote the use of renewable energy sources. Together with increasing oil prices, the result is a steady increase in the demand for renewable energy sources, for heat and power production and to a varying degree also for vehicle fuels. As a consequence, the need to secure a balance between biomass production/extraction and other ecosystem services (biodiversity, social and cultural values, etc) provided by forests and farmland is increasing as well.

The Commission presented in January 2008 a proposal for a directive that, among other things, aim to secure the sustainability and climate mitigating efficiency of renewable fuels for transport used within EU member states to meet the 2020 goals. The proposed criteria are presently being debated and processed.

In the Nordic countries Denmark, Norway, Finland and Sweden, the share of bioenergy production has increased relatively fast over the last decades, so far mainly in the form of rest products from forest and forest industry. However, the contribution from the agricultural sector has the potential to increase multiple times and it is possible that parts of both the Nordic and other European farmland that today are in fallow or used for food and fodder production will be used for cultivation of energy crops in the near future. An increase in production and extraction of biomass from forests and shifts in agricultural land use are likely to have effects on ecosystem processes and biodiversity. To avoid negative effects and to ensure the largest possible benefits of a conversion from fossil fuels to bioenergy it is important that the production of bioenergy is performed in a sustainable way.

One of the priorities of the Swedish Presidency of the Nordic Council of Ministers 2008 is climate. In the sector program of the Council of Ministers for Fisheries and Aquaculture, Agriculture, Foodstuffs and Forestry, the role of bioenergy in climate change is highlighted. This project is an input to this sector program and has been cofinanced by the Nordic Council of Ministers.

One aim of the project was to contribute to a promotion of practices that will reduce negative environmental impacts and improve the economic and social contribution of an increasing bioenergy production. Another aim of this project was to create an initiative and starting point for further Nordic cooperation to promote Nordic perspectives and viewpoints in EU and other regional processes where bioenergy production from forestry and agriculture is being discussed. 
Two workshops were arranged where expert knowledge of various sustainability criteria in relation to tried and/or existing implemented production systems were presented and discussed. Views from landowner representatives, NGO:s, other stakeholders and experts were included in the discussions.

This document summarizes the conclusions from the two workshops and describes general principles for a sustainable production of biofuels from agriculture and forestry in Denmark, Norway, Finland and Sweden.

The general principles of a sustainable production of biomass include practices that minimize negative effects on climate and environment. A key objective is efficiency throughout the whole production chain. A sustainable bioenergy system is resource efficient and energy efficient and has a high potential to mitigate climate change.

In addition, the production systems should have overall positive effects on social welfare and should be carried out with consideration to local communities and cultures.

The recommendations in Annex I aim to promote a production and extraction of biomass from agriculture and forestry that is carried out in a sustainable manner.

The principles and recommendations in this report can be used to help guiding policy-makers considering the adoption or revision of national recommendations and guidelines on this subject. The report can also be useful as a basis for information to landowners and users. 


\section{Sammanfattning}

Såväl i EU:s medlemsstater som i andra delar av världen har man ambitionen att öka andelen förnybara energikällor och minska förbrukningen av fossila bränslen. Tillsammans med ökade oljepriser leder detta till en stadigt ökande efterfråga på förnybara energikällor till både värme- och elproduktion samt även i varierande grad till produktion av drivmedel. Som en följd av detta ökar konflikterna mellan olika typer av markanvändning (produktion av livsmedel, foder och bränslen, biologisk mångfald, sociala och kulturella värden, etc.).

Kommissionen presenterade i januari 2008 ett förslag till direktiv vars syfte bland annat är att säkra att en ökad användning av förnybara drivmedel bidrar till en hållbar utveckling och reducerad klimatpåverkan. I förslaget, som för närvarande bearbetas, finns miljömässiga hållbarhetskriterier för biodrivmedel och andra biovätskor.

I de nordiska länderna Danmark, Norge, Finland och Sverige har produktionen av bioenergi ökat betydligt under de senaste åren. Än så länge rör det sig främst om restprodukter från skog och skogsindustri. Bidraget från jordbruket har dock potential att öka mångfaldigt och det är troligt att delar av både den nordiska och europeiska jordbruksmarken som idag är lagd i träda eller används för produktion av livsmedel och foder kan komma att användas för odling av energigrödor. En ökning av produktion och uttag av biomassa från skogen samt en förändring i användningen av jordbruksmark kan komma att få effekter på ekosystemens processer och den biologiska mångfalden. För att minska negativa effekter och maximera fördelarna med ett byte från fossila bränslen till bioenergi måste produktionen ske på ett hållbart sätt.

Under 2008 då Sverige haft ordförandeskapet i Nordiska Ministerrådet har bland annat klimatfrågan prioriterats. I sektorprogrammet för Nordiska Ministerrådet för fiskeri och havsbruk, jordbruk, livsmedel och skogsbruk lyfts aspekter kring bioenergins roll i klimatförändringen. Detta projekt är ett bidrag till detta sektorprogram och delfinansieras av Nordiska Ministerrådet.

Ett av syftena med projektet var att bidra till främjandet av metoder och tillämpningar som leder till en minskande negativ miljöpåverkan och förbättrar ekonomiska och sociala effekter av en ökande bioenergiproduktion. Ett annat syfte var att lägga grunden för ett fortsatt nordiskt samarbete i dessa frågor och ge ett samlat nordiskt perspektiv att användas i arbete på EU-nivå eller i andra regionala processer där frågor rörande bioenergi från jord- och skogsbruk behandlas.

Två arbetsseminarier har anordnats där spetskunskap rörande diverse hållbarhetskriterier i relation till olika befintliga produktionssystem pre- 
senterades och diskuterades. Synpunkter från representanter för markägare, NGO:s, andra intressenter samt experter togs emot under diskussionerna.

Detta dokument sammanfattar slutsatserna från båda arbetsseminarierna och beskriver allmänna principer för en hållbar produktion av biomassa i jord- och skogsbruk i Danmark, Norge, Finland och Sverige.

De generella principerna för hållbar produktion av biomassa inkluderar metoder och tillämpningar som minimerar negativa effekter på klimat och miljö. En nyckelfaktor är effektivitet genom hela produktionskedjan. Ett hållbart system för produktion av bioenergi är resurs- och energieffektivt samt har stor potential att minska negativ klimatpåverkan.

Dessutom bör produktionssystemet ha positiva effekter på social välfärd och ta hänsyn till lokal befolkning och kulturer.

Rekommendationerna i bilaga I syftar till att främja hållbar produktion och uttag av biomassa från jord- och skogsbruk.

Principerna och rekommendationerna i denna rapport kan användas både som vägledning för beslutsfattare i frågor inom detta ämne och som underlag för information till olika mark- och brukargrupper. 


\section{Introduction}

\subsection{An increasing bioenergy market}

There is an increasing awareness that climate change is caused by anthropogenic emissions of greenhouse gases that mainly originate from the use of fossil fuels. In the EU member states as well as in other parts of the world, energy policies are being developed that discriminate fossil fuels and /or promote the use of renewable energy sources. Together with increasing oil prices, the result is a steady increase in the demand for renewable energy sources, both for heat and power production and to a varying degree also for vehicle fuels. A transition to an economy that is more based on use of renewable biomass than on fossil fuels is initiated. As a consequence, conflicts between economic production of food, fodder and fuels and various ecosystem services (biodiversity, social and cultural values, etc) that are provided by forest and farmland are increasing as well. Hence, a developed thinking on how to balance between these services is desirable.

A sustainable production and extraction of biomass should not cause negative impacts on ecological, social or economical sustainable development.

Biofuels in this report is defined as solid, liquid and gaseous biomass-based fuels for the production of heat, electricity and/or transports.

\subsection{At the EU level}

The Commission presented in January 2008 a proposal for a directive that aim to further promote the use of renewable energy sources and thereby among other things contribute to climate change mitigation and a sustainable development. The proposal establish a target of a $20 \%$ share of renewable energy sources in energy consumption and a $10 \%$ target for biofuels in transport by the year 2020 .

The proposed directive sets up environmental sustainability criteria for biofuels and other bioliquids (note that biofuel in the proposal is used only in the meaning of liquid or gaseous fuel for transport produced from biomass). A primary aim is to sort out which biofuel use should qualify to be accounted for in the fulfilment of the EU targets. At present, the contents of the directive are being negotiated. A final version is expected before spring 2009. Requirements for a sustainability scheme for energy 
uses of biomass, other than biofuels for transportation and other bioliquids, are planned to be agreed on before the end of 2010 .

\subsection{Development in the Nordic region}

In the Nordic countries Denmark, Norway, Finland and Sweden, the share of bioenergy production has increased relatively fast over the last decades, so far mainly in the form of rest products from forest and forest industry. The forest sector is the main supplier for solid biofuels in northern Europe. However, with increasing market prices for bioenergy, the contribution from the agricultural sector has the potential to increase multiple times. It is possible that parts of the European farmland that today are in fallow or used for food and fodder production will be used for cultivation of energy crops in the near future. It is also probable that rest products (by-products) from both agriculture and forestry will be more intensively utilised for energy production in the future.

An increase in production and extraction of biomass from forests and shifts in agricultural land use are likely to have effects on ecosystem processes and biodiversity. It will also have economic and social effects, both at the local and national scale. To avoid negative effects and to ensure the largest possible benefits of a conversion from fossil fuels to bioenergy it is important that the production of bioenergy is performed in a sustainable way.

The countries of this region have overlapping climatic and environmental conditions and hence, an overlapping interest in the same types of systems for bioenergy production. They also share, to a growing extent, a common market for biofuels. While the potential to deliver larger volumes of biomass from forestry and agriculture for bioenergy production is still great, there is a need to analyse and distribute information about the various characteristics that define sustainable bioenergy production systems. Potentially, such work could contribute to increase acceptance of bioenergy production from forestry and agriculture, to provide a common platform for technical development and also facilitate communication of these qualities to forest owners, policy makers and other key actors. In addition, a common viewpoint on sustainability issues from the Nordic region may be used as input in the Community work aiming to avoid the development of multiple national schemes that could negatively affect trade to and within the Community.

\subsection{The project}

One of the priorities of the Swedish Presidency of the Nordic Council of Ministers 2008 is climate. In the sector program of the Council of Mini- 
sters for Fisheries and Aquaculture, Agriculture, Foodstuffs and Forestry, the role of bioenergy in climate change is highlighted. This project is an input to this sector program and has been cofinanced by the Nordic Council of Ministers.

The project was carried out during December 2007 - June 2008. One aim with the project was to contribute to a promotion of practices that will reduce negative environmental impacts and improve the economic and social contribution of an increasing bioenergy production.

Another aim of this project was to create an initiative and starting point for further Nordic cooperation to promote Nordic perspectives and viewpoints in EU and other regional processes where bioenergy production from forestry and agriculture is being discussed.

The project organized two workshops to:

- present and discuss available expert knowledge of various sustainability criteria in relation to tried and/or existing implemented production systems,

- collect views from land-owner representatives, NGO:s, other stakeholders and experts,

- gather and draft major conclusions in the form of recommendations.

This document summarizes the conclusions from the two workshops and describes general principles for a sustainable production of biofuels from agriculture and forestry in the Nordic countries Denmark, Norway, Finland and Sweden.

The principles and recommendations in this report can be used to help guiding policy-makers considering the adoption or revision of national recommendations and guidelines on this subject. 



\section{General principles}

The recommendations in Annex I aim to promote a production and extraction of biomass from agriculture and forestry that is carried out in a sustainable manner.

The production systems should have overall positive effects on social welfare and should be carried out with consideration to local communities and cultures.

A sustainable production of biomass includes practices that

- result in low greenhouse gas emissions,

- maintain and enhance biodiversity at the landscape level,

- maintain ecological processes and ecosystem functions,

- maintain vitality, productivity and regeneration capacity of production systems,

- preserve and protect areas of high nature conservation value,

- preserve cultural remains and heritages,

- restrict the consumption of finite resources such as oil, coal and minerals,

- minimize waste by promoting a circular flow of resources through for example recycling of nutrients,

- contribute to an increase in rural activity, economic development and energy security,

- promote possibilities for people to experience a diverse nature and possibilities for recreation.

A key objective is efficiency throughout the whole production chain. A sustainable bioenergy system is resource efficient and energy efficient and has a high potential to mitigate climate change.

- Resource efficiency means high biomass production per hectare, high utilization of existing residues and by-products, minimization of waste production and efficient nutrient recycling.

- Energy efficiency means that energy losses are minimized throughout the complete production chain, energy input relative output is low, etc.

- Climate mitigation efficiency means that greenhouse gas emissions from production are low and that the potential replacement of emissions from fossil fuels is high. 



\section{Annex I}

\section{Recommendations}

\section{A. Biomass production}

General:

Biomass production and extraction should comply with EU regulations and be performed in accordance with respective national regulations and recommendations that provide guidance on how to obtain a sustainable forestry and agriculture.

The production of biomass should be economically sustainable without subsidies in a long-term perspective to avoid the built-up of systems with long-term dependency on subsidy systems and unfair competition in relation to other renewable energy production systems.

Chemicals for insect and pest damage prevention should be used restrictively and according to national legislation and guidelines.

National authorities should provide information to producers on recommendations and recent development concerning the production. Monitoring programs should be promoted to assess that negative impact of practices are avoided.

\section{Energy efficiency:}

In the suggested EU directive for biofuels for transport, there are no targets for energy efficiency, only for greenhouse gas (GHG) emission savings. That means that e.g. ethanol produced very inefficiently using e.g. solid biofuels would be considered acceptable. However, we find energy efficiency to be an important criterion in a climate mitigation context, because the availability of "low-GHG" energy at low cost is limited. If savings can be achieved in one sector, more fossil fuels can be replaced by "low-GHG" energy in another sector. We also think that in a sound economic situation, biofuels that are produced in an inefficient way will not be competitive in the longer term, and we should not encourage the sector to invest in such production systems. 


\section{Suggestion for an indicative target for energy efficiency:}

For production of biomass as feedstock for heat and electricity production, the energy input in cultivation and fuel production should preferably be less than $20 \%$ of energy output if by-products in cultivation and processing are accounted for ${ }^{1}$.

For production of biomass as feedstock for the production of transport fuels, energy input should preferably be less than $50 \%$ of energy output.

Examples: For the major part of rest product biofuels used for heat production or combined heat and electricity production, the energy input is c. $5 \%$ of what is gained (input share). For production of willow and reed canary grass for heat/electricity, the energy input share is typically c. 5-10\%. Willow for methane or methanol would have an input share of $10-15 \%$. For production of wheat for ethanol, energy input could be c. $70 \%$ with no by-products from the field and the processing to be accounted for and below $30 \%$ with by-products. For rape seed-RME production, energy input is sometimes over $50 \%$ with no by-products and could be below $20 \%$ with by-products ${ }^{2}$.

\section{Climate mitigation efficiency}

Concerning climate mitigation efficiency there are two main criteria to consider. First, net greenhouse gas emissions of the actual production system should be low in relation to the emissions that can be avoided if a fossil fuel is replaced. Second, net greenhouse gas emissions caused by land-use conversion should not be high in relation to the amount of greenhouse gas emission that can be avoided in a certain time perspective.

In the suggested EU directive for biofuels for transport, a general criteria states that the greenhouse gas emission saving from the use of the fuel should be at least 35\%. Concerning land-use change, the draft directive text suggests that biofuels (to be accounted for when meeting targets) shall not come from wetlands transferred from a natural to a drained status or from land that was deforested after January 2008. Carbon losses in soils caused by changed cultivation system should be divided over 20 years and accounted for in the minimum limit of 35\% savings in a 20 year time perspective.

We think that this target is rather low in a Nordic perspective and that we could aim higher to avoid investment in short-lived production technologies. We also conclude that deforestation can be justified in cases when no important biodiversity is lost and the gain in climate mitigation is high in a 50-year time perspective and longer, even if the gain in 20 years time is relatively low. We also think that changes in carbon stocks should be distributed over 50 years rather than 20 years. The problem of

\footnotetext{
${ }^{1}$ In the case of production of fuels for transport: not considering the consumption phase. In case the cultivation and/or the processing also results in a by-product with economic value, the input energy should be distributed on all products based on a product value (average over some years) proportion basis. An exception from the energy efficiency limit could be motivated if the annual net energy gain in absolute figures is instead very high per hectare.

${ }^{2}$ Ref. Börjesson and Tufvesson, manuscript (200x).
} 
climate change is a challenge to find sustainable ways of using our natural resources. In 20 years time, we must reach a long way in the transformation away from fossil fuel dominated energy consumption. A too narrow perspective concerning carbon stocks in biomass and soil will not be helpful in this work.

\section{Suggestion for an indicative target for climate mitigation efficiency:}

Greenhouse gas emission savings ${ }^{3}$ from the production and use of biomass as feedstock for heat and electricity production should preferably be higher than $80 \%$ as compared to if oil had been used for the same purpose. At production and use of biofuels for transport, greenhouse gas emission saving should preferably be higher than $50 \%$ as compared to if oil had been used for the same purpose ${ }^{4}$.

Land conversion after January 2008, prior to production of biomass primarily used for energy production, should not result in GHG emissions higher than $30 \%$ of the potential emissions of all replaced oil in a 50-year perspective.

A land conversion example:

If a typical mid-latitude Nordic forest would be converted to short-rotation willow, an average $\mathrm{C}$ reservoir in forest biomass of c. 50 ton $\mathrm{C}$ per hectare would be replaced with an average of c. 15 ton $C$ in willow biomass. Additionally, potentially c. 10 ton $\mathrm{C}$ would be lost from the soil over a few decades. Thus, altogether there could be a loss of ca 45 ton C/ha.

Willow production for the use as an energy source could reduce emissions from oil combustion with $3-5$ ton $\mathrm{CO}_{2}$ - $\mathrm{C}$ per hectare and year. In 20 years time that is $60-100$ ton $\mathrm{C} / \mathrm{ha}$, in 50 years that is $150-250$ ton $\mathrm{C}$ and in 100 years that is $300-500$ ton $C$ that could be replaced. Concerning the short-term effect which is seemingly low-efficient from a mitigation point of view in this example, it could be further noted that any conversion of forest will be made after final harvest and at that stage there is yet many decades to go until the average stock is reached.

\section{B. Biofuel production in forestry}

\section{Biodiversity and landscape aspects}

Precautionary measures to sustain forest-dwelling species in viable populations should be taken from a landscape perspective rather than from stand level. This means that:

- Biofuel harvest should be conducted in relation to other management actions in the landscape so as to sustain forest biodiversity, including the regional recovery and persistence of endangered species.

\footnotetext{
${ }^{3}$ Including emissions of all important GHGs in $\mathrm{CO}_{2}$ equivalents.

${ }^{4}$ Like for energy efficiency, emissions should be shared between products and by-products on a product value basis.
} 
- Biofuel harvest should be conducted so that trees and dead-wood elements that are retained at cutting sites for promoting biodiversity are not removed or destroyed, and that biologically diverse forest habitats (e.g. ecotones, riparian zones, wet biotopes, wetlands) are not destroyed or degraded.

- Logging residues and stumps of certain tree species host endangered species. The extraction of these elements should be restricted and comply with detailed regulations.

At ash recycling, the ash should be sufficiently hardened to avoid negative effects on field vegetation.

Runoff water

Nitrogen fertilization should not result in significantly increased nitrogen leaching from the root zone.

No chemicals should be used in a way that might damage life in recipient water ecosystems.

Buffer zones should be left between clear-felled areas and waters and wetlands to avoid damage on water and near water zone qualities.

Damage on run-off water and ground water in connection with logging, transportation and soil scarification, should be avoided.

Soil properties

Humus, nutrients and acid/base contents should be kept at levels that at least maintain a natural soil production capacity and a natural quality of run-off water. In case addition of other nutrients than nitrogen is required to meet this target, ash recycling should be given priority. The ash shall have a natural element composition and be in a low-reactive form.

\section{Social aspects}

No practices that might threaten the health status of forest workers should be used.

In case of introductions of new techniques, monitoring of effects on workers health status may be needed.

\section{Biofuel production in agriculture}

\section{General}

Production of energy-crops should meet energy efficiency recommendations (cf above). The use of perennial species may contribute to a reduced energy input greenhouse gas emissions as well as consumption of pesticides and fertilizers. 
Frequent tillage should be avoided on organogenic soil ${ }^{5}$. Organogenic soils are therefore well suited for cultivation of crops with long regeneration ${ }^{6}$ cycles.

\section{Biodiversity and landscape aspects}

Production should not endanger biodiversity at the landscape level. However, special considerations to threatened species should be taken at the local level.

Sustained or increased variation of the landscape should be promoted.Crop rotation should be applied when annual crops are cultivated.

When extracting biofuels from meadows or pastures, species of shrubs and small trees that are less frequent in the landscape should be left standing.

The development of increased bioenergy crop production in agriculture should not be allowed to threaten the preservation of meadows and pasture land with high conservation values. However, biomass generated when managing such meadows and pastureland may be used for energy production.

In case production economy poses a threat for conversion of valuable meadows or pastureland into arable land, positive incentives for increased preservation should be considered for mitigation.

To make use of the added values of short rotation forestry (SRF) plantations they should be located, designed and managed in such a way that they contribute to a varied landscape. This means:

- Leaving buffer zones around the edges of SRF-plantations in order to support the development of a rich native flora and fauna.

- Planting and harvesting different parcels of the SRF-plantations in different years in order to enhance structural diversity and biodiversity.

- Locating SRF-plantations close to existing native woodlands or incorporating patches with native trees within larger plantations ensure the presence of refugees for organisms during periods of clearcut of the SRF-plantation.

Runoff water:

Eutrophication should be avoided and any addition of nutrient fertilizer should therefore be adjusted to the crop demand during the growing season. The use of black water and sludge as fertilizers must be done in a way that guarantees that no contamination of waters occurs.

Chemicals should be used restrictively and in a way that no damage of life in recipient water ecosystems is caused.

\footnotetext{
${ }^{5}$ Organogenic soils are characterized by a high content of organic material (peat soils and mud soils).

${ }^{6}$ Regeneration in the meaning of tillage and replanting
} 
Soil properties:

Avoid cultivation methods that cause depletion of humus, nutrients and minerals in the soil below levels necessary for the maintenance of the long-term soil production capacity.

A high ambition to recycle nutrients in waste products from food and fodder processing and consumption should be encouraged.

Ash that originates from farmland should be recycled. The ash shall have the composition and be spread according to current recommendations. Use methods that avoid erosion and harvesting damages. Harvest should be performed during periods of frozen ground when applicable and possible.

Social aspects:

Activities should have generally positive effects on social welfare and should be carried out with consideration to local communities and cultures. 


\section{Annex II}

Participants at Workshop I, 10-11 March in Jönköping

- Alarik Sandrup, LRF, The Federation of Swedish Farmers

- Anna Lundborg, Swedish Energy Agency

- Birgitta Naumburg, Ministry of Agriculture, Sweden

- Bruce Talbot, Forest \& Landscape, University of Copenhagen, Denmark

- Christel Gustafsson, Swedish Board of Agriculture

- Eila Turtola, MTT Agrifood Research Finland

- Eva Dalenstam, The Swedish Environmental Management Council

- Frode Lyssandtrce, Landbruks- og matdepartementet, Norway

- Håkan Berglund, Dept. of Ecology, Swedish University of Agricultural Sciences

- Hillevi Eriksson, Swedish Forest Agency

- Johanna Ikävalko, Central Union of Agricultural Producers and Forest Owners, Finland

- Kaisa Pirkola, Ministry of Agriculture and Forestry, Dept. of Forestry, Finland

- Karin Fällman, Forest Stewardship Council, Sweden

- Lars Andersson, Swedish Forest Agency

- Lena Niemi, Swedish Board of Agriculture

- Marie-Louise Bretner, Dansk Skovforening, Denmark

- Martin Weih, Dept. of Crop Production Ecology, Swedish Univ. of Agricultural Sciences

- Mathias Gustavsson, The Swedish Society for Nature Conservation

- Mats Dynesius, Dept. of Ecology and Environmental Science, Umeå University

- Morten Ingerslev, Forest \& Landscape, University of Copenhagen, Denmark

- Pål Börjesson, Dept. of Technology and Society, University of Lund

- Peter Blombäck, Swedish Forest Agency

- Rasmus Moes, Skov- og Naturstyrelsen, Norway

- Veli-Pekka Reskola, Ministry of Agriculture and Forestry, Dept. of Agriculture, Finland 
Participants at Workshop II, 6-7 May in Jönköping

- Christel Gustafsson, Swedish Board of Agriculture

- Fredrik von Unge, Ministry of Agriculture, Sweden

- Hans Rolandsson, Swedish Board of Agriculture

- Hillevi Eriksson, Swedish Forest Agency

- Ingemar Gruvaeus, Hushållningssällskapet, Sweden

- Jan-Erik Mattsson, Department of Agriculture - Farming Systems, Technology and Product Quality, Swedish University of Agricultural Sciences

- Kaisa Pirkola, Ministry of Agriculture and Forestry, Dept. of Forestry, Finland

- Lena Niemi, Swedish Board of Agriculture

- Marie-Louise Bretner, Dansk Skovforening, Denmark

- Peter Blombäck, Swedish Forest Agency

- Peter Roberntz, WWF, Sweden

- Simen Gjølsjø, Norwegian Forest and Landscape Institute

- Stig Widell, Swedish Board of Agriculture

- Sven Hogfors, Svenska trädbränsleföreningen

- Thomas Prade, Department of Agriculture - Farming Systems, Technology and Product Quality, Swedish University of Agricultural Sciences

- Veli-Pekka Reskola, Ministry of Agriculture and Forestry, Dept. of Agriculture, Finland 